\title{
Метод розрахунку теплообміну під час конденсації холодоагентів у середині горизонтальних труб у разі стратифікованого режиму течії фаз
}

\author{
В. В. Горін ${ }^{1 凶}$, В. В. Середа ${ }^{2}$, П. О. Барабаш ${ }^{3}$ \\ ${ }^{1}$ Одеська державна академія технічного регулювання та якості, вул. Ковальська, 15, м. Одеса, 65020, Україна \\ ${ }^{2}$ Національний університет водного господарства та природокористування, вул. Соборна, 11, м. Рівне, 33028, Україна \\ ${ }^{3}$ Національний технічний університет України «Київський політехнічний інститут імені Ігоря Сікорського», \\ вул. Політехнічна, 6, м. Київ, 03056, Україна \\ \e-mail: ${ }^{1}$ gorin53@ukr.net, ${ }^{2}$ volodya.81.vs@gmail.com
}

У сучасних конденсаторах систем кондиціонування повітря, теплових насосів, випарниках систем опріснювання морської води і нагрівачах електростанцій процес конденсації пари здійснюється переважно у середині горизонтальних труб і каналів. Процеси теплообміну, щзо відбуваються у теплообмінниках изього типу, мають суттєвий вплив на загальну енергоефективність таких систем. У даній роботі представлено експериментальні дослідження теплообміну у разі конденсації холодоагентів R22, R406A, R407C y гладкій горизонтальній трубі з внутрішнім діаметром $d=17$ мм за наступними режсиними параметрами:температура насичення 35 - 40 $\mathrm{C}$, масова швидкість 10 - 100 кг/кв.м/с, масовий паровміст 0,1 - 0,8, питомий тепловий потік 5 - 50 кВт/кв.м, різниця між температурою конденсації та температурою стінки труби 4 - 14 K. Вимірювання локальних за перерізом труби теплових потоків і коефіцієнтів тепловіддачі проводились за методом «товстої стінки» під час різних режимів конденсації. За результатами досліджень установлено, щуо у верхній частині труби з підвищенням теплового потоку зростає товщина плівки конденсату, щзо призводить до зменщення тепловіддачі. У нижній частині труби збільщення теплового потоку підвищує тепловіддачу, щуо характерно для турбулентної течї̈ рідини в трубі. Отримані результати роботи дозволили покращити метод розрахунку теплообміну у разі конденсації пари, яка ураховує вплив течї конденсату у нижній частині труби на теплообмін. Цей метод із достатньою точністю (похибка $\pm 30 \%)$ узагальнює експериментальні дані під час конденсації пари холодоагентів R22, R134a, R123, R125, R32, R410а за умови стратифікованого потоку. Використання цъвого методу у разі проектування теплообмінних апаратів, які використовують такі типи речовин, підвищить ефективність енергетичних систем.

Ключові слова: конденсачія, теплообмін, теплообмінник, гладка труба, стратифікований режим.

doi:

(C) The Author(s) 2019. This article is an open access publication

This work is licensed under the Creative Commons Attribution 4.0 International License (CC BY) http://creativecommons.org/licenses/by/4.0/

\section{1 Вступ}

У даний час наявні методи й моделі щодо розрахунку теплообміну у разі конденсації двофазних потоків у середині горизонтальних труб мають відмінності між собою. Ця неточність обумовлена наявністю великої кількості параметрів, що впливають на тепловіддачу, широкого діапазону змін цих параметрів. Наприклад, геометричні розміри (довжина і діаметр труб), теплофізичні властивості (теплопровідність, густина, поверхневий натяг тощо) рідин, що конденсуються, і робочі параметри (тиск, масова швидкість, тепловий потік) варіюються в межах 10 - 100 разів у теплообмінних апаратах. Неточна оцінка тепловіддачі може призвести до необгрунтованої зміни розмірів апарату і перепадів тиску, які або збільшуються, або зменшуються, що призводить до зниження ефективності. Також, відсутність точності оцінки тепловіддачі призводить до неточної оцінки ефективності різних методів інтенсифікації процесу теплообміну під час конденсації у горизонтальних трубах.

У зв'язку з цим, важливо виконати нові дослідження у області впливу режимних параметрів двофазного потоку на закономірності теплообміну у разі конденсації пари, що рухається у горизонтальній трубі. Ці дослідження відкриють можливість розробки нового методу розрахунку теплообміну у разі конденсації різних холодоагентів усередині горизонтальних труб теплообмінних апаратів. Більш точна оцінка тепловіддачі та режимних параметрів дозволить підвищити ефективність роботи горизонтальнотрубних конденсаторів.

Ця робота $є$ третьою частиною циклу робіт із дослі- 
дження гідродинаміки й теплообміну під час конденсації у середині труб у разі стратифікованого режиму течії фаз $[1,2]$.

\section{2 Характерні особливості процесу конден- сації}

Під час плівкової конденсації у горизонтальній трубі можливий широкий діапазон різних режимів течії плівки конденсату і розподілу фаз (рис. 1). Розподіл цих режимів залежить від фізичних властивостей пари і конденсату, діаметра труби і іiі орієнтації, швидкості пари і теплового потоку. Основні режими течії фаз можуть бути класифіковані наступним чином:

1. На вході трубки спостерігається кільцевий режим течії фаз із ламінарною течією плівки конденсату. $\mathrm{y}$ випадку великих швидкостей пари можливий зрив конденсату i у цьому випадку має місце дисперсний режим течії фаз. У разі зменшення швидкості пари відбувається перехід від ламінарної течії плівки конденсату у турбулентну.

2. На певній відстані від входу до труби спостерігається асиметрична течія плівки конденсату. Це відбувається тому, що під дією гравітації плівка конденсату стікає під певним кутом до горизонталі. У нижній частині труби потік плівки конденсату турбулентний, а у верхній частині - ламінарний. У цьому випадку спостерігається проміжний або напівкільцевий режими течії фаз.

3. У разі, коли сили тяжіння перевищують сили між фазного тертя, за низьких масових паровмістів має місце стратифікований режим течії фаз. При цьому у верхній частині труби конденсат стікає під кутом, близьким $90^{\circ}$ до горизонталі, тоді як у нижній частині труби він тече у вигляді потоку струмка за рахунок градієнта статичного тиску. За низької швидкості пари на вході в трубу цей режим може спостерігатися за всією довжиною труби.

Отже, у відповідності з такою класифікацією режимів течії фаз розробляються методи розрахунку теплообміну.

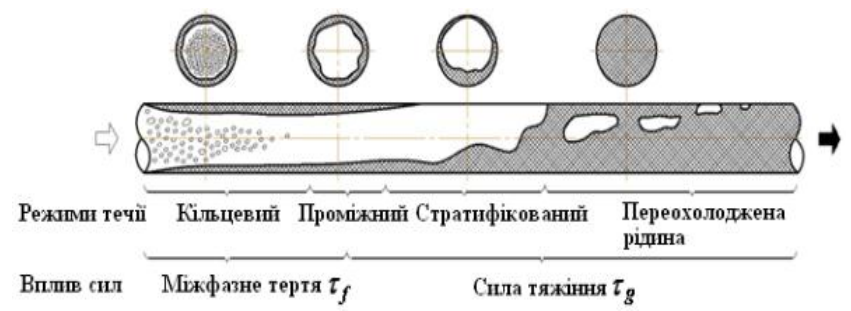

Рисунок 1 - Основні режими течї фаз під час конденсаиї у горизонтальній трубi

\section{3 Методи розрахунку тепловіддачі}

До теперішнього часу були опубліковані майже сотні досліджень у разі конденсації у середині звичайних труб і каналів. На підставі всебічного огляду опублікованих досліджень, кореляції, що запропоновані Thome et al. [3], Cavallini et al. [4], Shah [5], Rifert et al. $[6,7]$, рекомендуються використовувати щодо точного розрахунку коефіцієнтів тепловіддачі у разі конденсації під час кільцевого й проміжного режимів течії фаз. Однак, у випадку стратифікованого режиму течії фаз немає чіткої впевненості стосовно використання різних розрахункових залежностей. У більшості випадків тепловіддача у цьому випадку обчислюється за формулою Нуссельта (1) [8], отриманої для конденсації пари на зовнішній поверхні горизонтальної труби з урахуванням або без врахування тепловіддачі в потоці конденсату (рис. 1). У більшості випадків теплообмін у потоці обчислюється за формулами у разі конвективного теплообміну за турбулентному русі рідини.

$$
\alpha_{\text {strat }}=0,728\left(\frac{\rho_{l}\left(\rho_{l}-\rho_{v}\right) g r \lambda_{l}^{3}}{\mu_{l} d \Delta T}\right)^{1 / 4} .
$$

У роботі [9] показано, що автори більшості публікацій не досліджували вплив теплового потоку на характер теплообміну, а вивчали вплив масових швидкості $G$ і паровмісту $x$. Також відсутні вимірювання коефіцієнтів тепловіддачі у потоці конденсату, де їх значення набагато нижчі, ніж у верхній частині труби, і немає чітких рекомендацій щодо границь застосування запропонованих розрахункових залежностей.

\section{4 Матеріальне та методичне забезпечення експериментальних досліджень}

Для проведення експериментальних досліджень теплообміну у разі конденсації холодоагентів у середині горизонтальних труб використовувалась експериментальна установка, опис якої, а також методика проведення експериментів стосовно дослідження локальних характеристик теплообміну наведено у праці [10]. У роботі [10], у разі експериментального визначення коефіцієнтів тепловіддачі, запропоновано метод, у якому локальний тепловий потік визначається за градієнтом температур у стінці товстостінної труби з подальшим розрахунком розподілу температури за поверхнею теплообміну градієнтів температур на границі «стінка речовина», та розподілу локальних коефіцієнтів тепловіддачі за поверхнею теплообміну.

Основні режимні параметри двофазної течії у робочий ділянці визначали шляхом розв'язання рівняння матеріального і теплового балансів, записаних для неї. Досліди проводились за наступними діапазонами змінювання режимних параметрів: температура насичення $t_{s}=35-40^{\circ} \mathrm{C}$, масова швидкість $G=10-100 \mathrm{\kappa г} /\left(\mathrm{m}^{2} \cdot \mathrm{c}\right)$, локальний масовий паровміст $x=0,1-0,8$, густина локального теплового потоку $\mathrm{q}_{\varphi}=5-50$ кВт/м $\mathrm{M}^{2}, \Delta \mathrm{T}=4$ - 14 К. Усі експерименти виконувалися для однакових $\mathrm{G}$ i $x$, але з змінними $q_{\varphi}$. Така процедура дозволяла стабільно підтримувати однакові параметри процесу конденсації $(G$ і $x)$ під час експериментів.

\section{5 Визначення режимів течії}

У разі визначення режимів течії фаз у роботі використовувався метод 3 робіт Rifert et al. [6, 7]. Граничне значення співвідношення сил між фазного тертя $\tau_{f}$ до сил тяжіння $\tau_{g}$ обчислюється таким чином:

$$
\begin{aligned}
& \text { - за } \tau_{f} / \tau_{g}>10 \text { - кільцевий режим; } \\
& \text { - за } 1 \leq \tau_{f} / \tau_{g} \leq 10 \text { - проміжний режим; }
\end{aligned}
$$


- за $\tau_{f} / \tau_{g}<1$ - стратифікований режим; (4)

$$
\begin{aligned}
& \tau_{f}=C_{f} \rho_{v} w_{v}^{2} / 2, \\
& \tau_{g}=\rho_{l} g \delta .
\end{aligned}
$$

Значення товщини плівки $\delta$ розраховують за рівнянням

$$
\delta^{+}=\delta / v_{l}\left(\tau_{f} / \rho_{l}\right)^{0,5}
$$

де безрозмірна товщина плівки $\delta^{+}$залежить від значення $\operatorname{Re}_{l}$ :

$$
\begin{aligned}
& \operatorname{Re}_{l}<50, \delta^{+}=0,7071 \operatorname{Re}_{l}^{0,5} \\
& \operatorname{Re}_{l} \leq 1125, \delta^{+}=0,4818 \operatorname{Re}_{l}^{0,585} \\
& \operatorname{Re}_{l}>1125, \delta^{+}=0,095 \operatorname{Re}_{l}^{0,812}
\end{aligned}
$$

Авторами праць [6, 7] запропоновано визначити коефіцієнт тертя двофазного потоку $C_{f}$ у формулі (5) відповідно до залежності (11). Формула (11) дозволяє оцінити як вплив двофазності потоку (множник $\Phi_{v}^{2}$ ), так і всмоктування пари на границі фаз (множник $\Phi_{q}$ ) на коефіцієнт тертя $C_{f}$ i, відповідно, на між фазне терТя $\tau_{f}$.

$$
C_{f}=C_{f_{0}} \Phi_{v}^{2} \Phi_{q},
$$

де $C_{f_{0}}=0,079 / \operatorname{Re}_{v}^{0,25}$ за $\operatorname{Re}_{v} \leq 10^{5}$

або $C_{f_{0}}=0,046 / \operatorname{Re}_{v}^{0,2}$ за $\operatorname{Re}_{v}>10^{5}$.

Множники $\Phi_{v}^{2}$ і $\Phi_{q}$ визначаються за рівняннями (12) i (13):

$$
\Phi_{v}^{2}=1+C X_{t t}^{n}+X_{t t}^{2}
$$

де

$$
\begin{aligned}
& C=21\left\{1-\exp \left(1-0,28 B o^{0,5}\right)\right\} \times \\
& \left\{1-0,9 \exp \left(-0,02 F r^{1,5}\right)\right\} \\
& B o=\frac{g d_{i}^{2}\left(\rho_{l}-\rho_{v}\right)}{\sigma}, \\
& F r=\frac{G x}{\sqrt{g d_{i} \rho_{v}\left(\rho_{l}-\rho_{v}\right)}}
\end{aligned}
$$

і показник ступеню $n=1-0,7 \exp (-0,08 F r)$.

$$
\Phi_{q}=1+17,5 \mathrm{Re}_{v}^{0,25} \frac{q}{r G x} .
$$

\section{6 Розробка методу розрахунку теплообміну}

Вплив локального за периметром труби теплового потоку $q_{\varphi}$, на локальні значення коефіцієнтів тепловіддачі різний залежно від кутової координати $\varphi$. Для всіх дослідів значення $\alpha_{\varphi}$ у верхньому сегменті труби $\left(\varphi>90^{\circ}\right)$ зменшуються зі збільшенням $q_{\varphi}$ (рис. 2 ).

Це пояснюється тим, що у разі збільшення теплового потоку товщина плівки конденсату також зростає, що призводить до зменшення тепловіддачі. За $\varphi<90^{\circ}$ у нижній частині труби (у струмку конденсату) $\alpha_{\varphi}$ зростає за умови збільшення $q_{\varphi}$ (рис. 4). Такий вплив теплового потоку на теплообмін характерний у разі турбуле- нтної течії рідини у трубі. Із рис. 4 видно, що експериментальні значення $\alpha_{\varphi}$ У верхній частині труби $\left(\varphi>90^{\circ}\right)$ досить точно узгоджуються із розрахунком за формулою Нуссельта (1). Такий результат відповідає теорії плівкової конденсації і співпадає із даними робіт [3, $11-13]$.

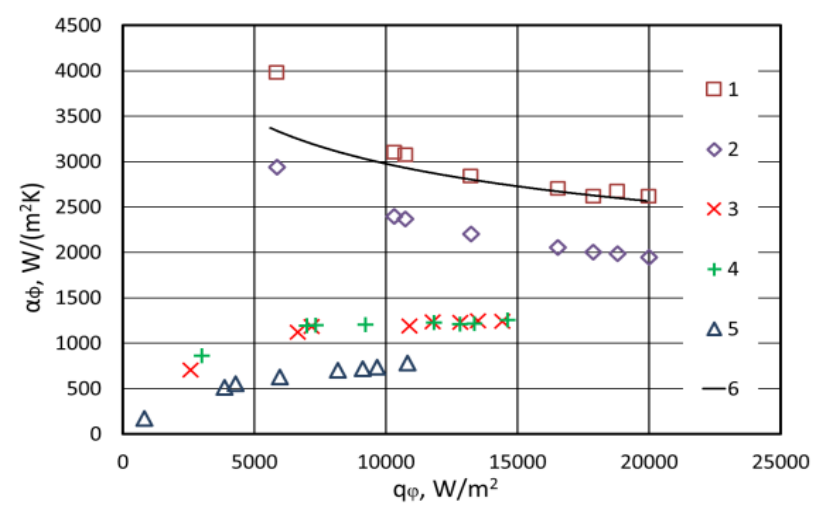

Рисунок 2 - Вплив теплового потоку $q_{\varphi}$ на локальну за периметром труби тепловіддачу $\alpha_{\varphi}$ у разі значень $G=43 \kappa 2 /\left(\mu^{2} \cdot c\right)$ i $x=0,24: 1-\varphi=0^{\circ} ; 2-\varphi=45^{\circ}$; $3-\varphi=90^{\circ} ; 4-\varphi=135^{\circ} ; 5-\varphi=180^{\circ}$;

6 - розрахунок за формулою (1) у разі $\varphi=180^{\circ}$

У разі розрахунку теплообміну у нижній частині труби, необхідно знати геометричні параметри струмка конденсату (рис. 3).

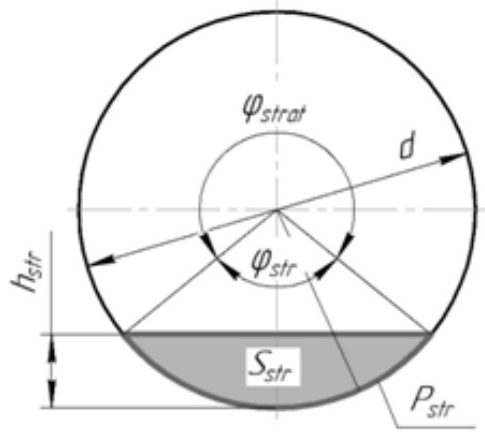

\section{Рисунок 3 - Геометричні параметри струмка конденсату за умови стратифікачійного режиму}

Автори праці [1] виконали порівняльні розрахунки кута затоплення труби $\varphi_{s t r}$ і висоти струмка $h_{s t r}$ за різними теоретичними та емпіричними залежностями. У [1] показано, що найбільш прийнятною формулою для розрахунку кута затоплення труби струмком конденсату є залежність Консетова (14) $[14,15]$. Геометричні параметри струмка конденсату у зазначеній роботі визначаються за залежностями (15) - (18):

- кут затоплення труби, рад:

$$
\varphi_{s t r}=2\left\{\arccos \left[1-4,2 F r^{1 / 3}\left(\frac{\sigma}{\rho_{l} g d_{i}^{2}}\right)^{1 / 4}\right]+\pi\left(\frac{\sigma}{\rho_{l} g d_{i}^{2}}\right)^{1 / 2}\right\}
$$

- висота струмка конденсату, м: 


$$
h_{s t r}=\frac{d}{2}\left(1-\cos \frac{\varphi_{s t r}}{2}\right)
$$

- площа труби, яка затоплена конденсатом, м²

$$
S_{s t r}=d^{2} / 8\left(\varphi_{s t r}-\sin \varphi_{s t r}\right) ;
$$

- периметр контакту струмка конденсату зі стінкою труби, м:

$$
P_{s t r}=d_{s t r}\left[\varphi_{s t r} / 2+\sin \left(\varphi_{s t r} / 2\right)\right]
$$

- еквівалентний діаметр струмка, м:

$$
d_{s t r}=4 S_{s t r} / P_{s t r}
$$

Залежність щодо розрахунку конвективного теплообміну у нижній частині труби $\left(0 \leq \varphi \leq \varphi_{s t r}\right.$, рис. 3$) \alpha_{b o t}$ має вигляд

$$
\alpha_{b o t}=N u_{b o t} \frac{\lambda_{l}}{d_{s t r}}=c \operatorname{Re}_{s t r}^{n} \operatorname{Pr}_{l}^{0.5} \frac{\lambda_{l}}{d_{s t r}}
$$

де $\operatorname{Re}_{s t r}=w_{s t r} d_{s t r} / v_{l}$ - число Рейнольдса у струмку конденсату; $w_{s t r}$ - швидкість руху конденсату у струмку, м/с.

Для визначення коефіцієнтів $c$ та $n$ у формулі (19) проведені дослідження конденсації холодоагентів $R 22$, $R 406$ A і $R 407 \mathrm{C}$ саме у разі їх стратифікованого режиму течії. На рис. 4 експериментальні значення $\alpha_{\varphi}$ у нижній частині труби ( $\varphi=0^{\circ}$ та $45^{\circ}$, рис. 3$)$ узагальнено наступною кореляцією:

$$
N u_{s t r}=0.0161 \operatorname{Re}_{s t r}^{0.842} \operatorname{Pr}_{l}^{0.5}
$$

достовірність апроксимації становить $R^{2}=0,9521$.

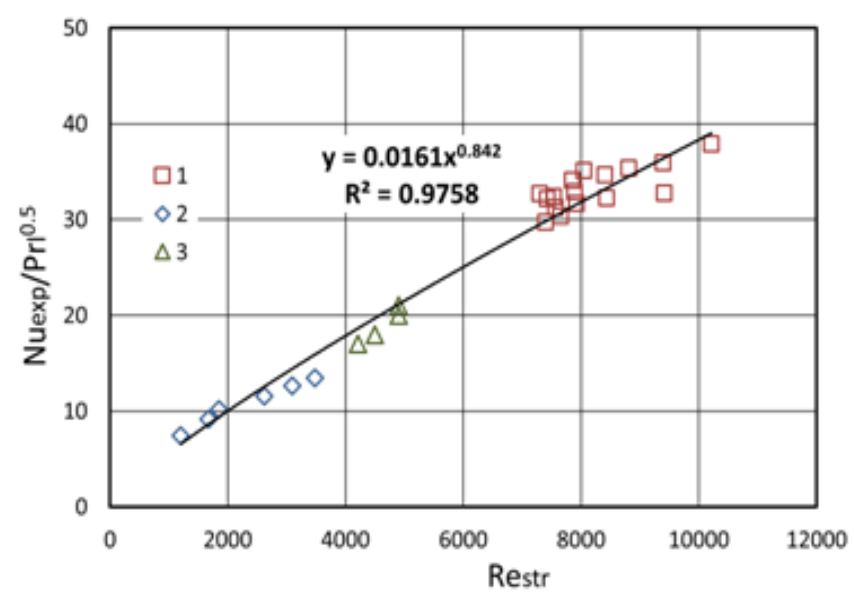

Рисунок 4 - Апроксимація експериментальних даних у разі конденсації холодоагентів: 1-R22; $2-R 407 C ; 3-R 406 A$ y вигляді $N u_{\text {stream }}=f\left(\operatorname{Re}_{\text {str }}, \operatorname{Pr}_{l}\right)$

Таким чином, формула (21) буде мати наступний вигляд:

$$
\alpha_{b o t}=0.0161 \operatorname{Re}_{s t r}^{0.842} \operatorname{Pr}_{l}^{0.5} \frac{\lambda_{l}}{d_{s t r}}
$$

Отже, розрахунок теплообміну у разі стратифікованого режиму течії фаз рекомендується виконувати за наступним алгоритмом:

1. Розрахувати кут затоплення струмком конденсату нижньої частини труби $\varphi_{s t r}$ за формулою (14) та геометричні параметри струмка за формулами (15) - (18).

2. Визначити коефіцієнт тепловіддачі у верхній частині труби $\left(\varphi_{s t r} \leq \varphi \leq \varphi_{\text {strat }}\right) \alpha_{\text {top }}$ за формулою (1).

3. Значення коефіцієнта тепловіддачі у струмку конденсату $\left(0 \leq \varphi \leq \varphi_{s t r}\right) \alpha_{b o t}$, розрахувати за формулою (21).

4. За значеннями коефіцієнтів тепловіддачі $\alpha_{t o p} \mathrm{i}$ $\alpha_{b o t}$, а також кута затоплення $\varphi_{s t r}$ розрахувати локальні за довжиною труби коефіцієнти тепловіддачі $\alpha_{\text {strat }}$ за формулою (22):

$$
\alpha_{\text {strat }}=\frac{\alpha_{t o p}\left(2 \pi-\varphi_{s t r}\right)+\alpha_{b o t} \varphi_{s t r}}{2 \pi}
$$

\section{7 Верифікація запропонованого методу 3 експериментальними даними інших авто- рів}

Стосовно підтвердження точності розробленого методу, у роботі виконано його верифікацію з експериментальними даними з праць [16] і [17]. У роботі [16] досліджувалась конденсація у середині труб холодоагентів $R 22, R 134 \mathrm{a}, R 125, R 32$ і $R 410 \mathrm{a}$, а у роботі [17] $R 22, R 123$ і $R 134$. Для верифікації з зазначених робіт були вибрані тільки такі дані, які відповідали стратифікованому режиму течії фаз. Результати порівняння приведені на рисунку 5.

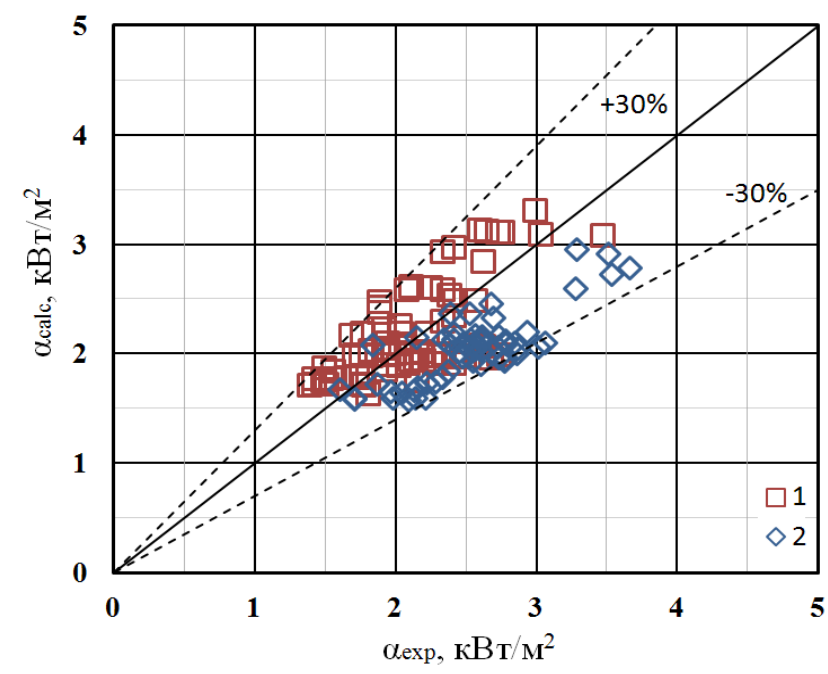

Рисунок 5 - Порівняння результатів розрахунку за запропонованим методом із експериментальними даними під час конденсачї:

1 - холодоагентів R22, R134a, R125, R32 і R410a [16]; 2 - холодоагентів $R 22, R 123$ і R134a [17]

3 рисунка 5 видно, що запропонований метод розрахунку теплообміну досить точно описує експериментальні дані у разі конденсації холодоагентів із робіт [16] i [17] у межах $\pm 30 \%$. 


\section{Висновки}

У результаті експериментальних досліджень під час конденсації холодоагентів $R 22, R 406 \mathrm{~A}, R 407 \mathrm{C}$ у середині горизонтальної труби під час стратифікованого режиму течії фаз, можна сформулювати наступні висновки:

1. Показано різний характер впливу теплового потоку на теплообмін у верхній та нижній частині труби.

2. Уточнено модель розрахунку теплообміну у разі конденсації під час стратифікованого режиму течії фаз. Отримана модель, яка $є$ відмінною від інших формул, та більш точно враховує вплив на теплообмін течії конденсату у нижній частині труби. Верифікація методу показала її досить точне узгодження $( \pm 30 \%)$ із даними по конденсації різних речовин у широкому діапазоні зміни режимних параметрів.

3. Наведену модель доцільно застосовувати у разі конденсації різних холодоагентів у середині горизонтальних труб. Для інших речовин дана модель потребує уточнення.

\section{Перелік умовних позначень і символів}

$C_{f} \quad$ - коефіцієнт тертя двофазного потоку

$C_{f o} \quad-$ коефіцієнт тертя однофазного потоку

$d$ - внутрішній діаметр труби, [м]

$F r_{l}-$ liquid Froude number $\left(=\frac{[G(1-x)]^{2}}{\rho_{l}^{2} g d}\right)$

$G \quad$ - масова швидкість, [кг/( $\left.\left.{ }^{2} \mathrm{c}\right)\right]$

$g-$ прискорення вільного падіння, [м/ $\left.\mathrm{c}^{2}\right]$

$l$ - довжина труби, [м]

$N u$ - число Нуссельта $\left(=\alpha d / \lambda_{l}\right)$

$\operatorname{Pr} \quad$ - число Прандтля

$q-$ питомий тепловий потік, $\left[\mathrm{BT} / \mathrm{M}^{2}\right]$

$q_{\varphi}$ - локальній за периметром труби тепловий потік, $\left[\mathrm{BT} / \mathrm{M}^{2}\right]$

$r \quad$ - питома теплота пароутворення, [Дж/кг]

$R e_{l}$ - число Рейнольдса для рідини,

$$
\left(\operatorname{Re}_{l}=G(1-x) d / \mu_{l}\right)
$$

$R e_{v}-$ число Рейнольдса для пари

$$
\left(\operatorname{Re}_{v}=G x d / \mu_{v}\right)
$$

$t \quad$ - температура, $\left[{ }^{\circ} \mathrm{C}\right]$

$w$ - швидкість, [м/с]

$x-$ масовий паровміст

\section{Грецькі символи:}

$\alpha-$ коефіцієнт тепловіддачі, [Вт/( $\left.\left.\mathrm{м}^{2} \mathrm{~K}\right)\right]$

$\alpha_{\varphi} \quad$ - локальний за периметром труби коефіцієнт тепловіддачі, [Вт/( $\left.\left.{ }^{2} \mathrm{~K}\right)\right]$

$\delta$ - товщина плівки конденсату, [м]

$\Delta T$ - різниця між температурою конденсації і температурою стінки труби $\left(\mathrm{t}_{\mathrm{s}}-\mathrm{t}_{\mathrm{w}}\right),[\mathrm{K}]$

$\lambda-$ коефіцієнт теплопровідності, [Вт/(мК)]

$\mu \quad$ - коефіцієнт динамічної в'язкості, [Па·с]

$v$ - коефіцієнт кінематичної в'язкості, $\left[\mathrm{m}^{2} / \mathrm{s}\right]$

$\rho-$ густина, $\left[\right.$ кг/ $\left.\mathrm{M}^{3}\right]$

$\sigma-$ коефіцієнт поверхневого натягу, [H/M] $\tau_{f} \quad$ - напруга тертя на межі поділу фаз, [Па]

$\tau_{g} \quad$ - сила тяжіння, [Па]

$\varphi \quad$ - кутова координата, [ $\left.{ }^{\circ}\right]$

$\Phi_{v}^{2}-$ множник для визначення впливу двофазності

конденсаційного потоку на напругу тертя

$\Phi_{q}$ - множник для визначення впливу теплового потоку на напругу тертя

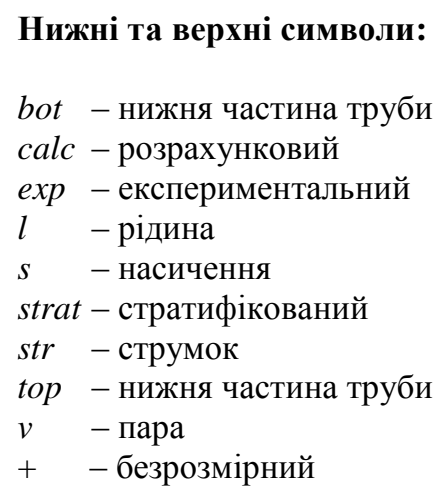

\section{Література}

1. Горін В.В., Середа В.В. Гідродинаміка та теплообмін під час конденсації пари робочих речовин у середині горизонтальних труб у разі стратифікованого режиму течії фаз. Огляд праць. Холодильна техніка та технологія. 2018. Том 54, вип. 4. С. 21-26.

2. Середа В.В., Горін В.В. Гідродинаміка і теплообмін під час конденсації пари робочих речовин у середині горизонтальних труб у разі стратифікованого режиму течії фаз. Розрахунок тепловіддачі. Інтегровані технології та енергозбереження. 2018. № 4. С. 48-56.

3. Thome J., El Hajal J., Cavallini A. Condensation in horizontal tubes. Part 2: New heat transfer model based on flow regimes. International Journal of Heat and Mass Transfer, 2003, Vol. 46, No. 18, p. 3365-3387.

4. Cavallini A., Del Col D., Doretti L., Matkovic M., Rossetto L., Zilio C., Censi G. Condensation in horizontal smooth tubes: a new heat transfer model for heat exchanger design. Heat transfer engineering, 2006, Vol. 27, No. 8, p. 31-38.

5. Shah M. An improved and extended general correlation for heat transfer during condensation in plain tubes. ASHRAE Transactions, 2009, No. 15, p. 889-913.

6. Rifert V., Sereda V., Gorin V., Barabash P., Solomaha A. Substantiation and the range of application of a new method for heat transfer prediction in condensing inside plain tubes. Energetika, 2018, Vol. 64, No. 3, p. 146-154.

7. Rifert V., Sereda V., Gorin V., Barabash P., Solomaha A. Restoration of correctness and improvement of a model for film condensation inside tubes. Bulgarian Chemical Communications, 2018, Vol. 50, No. K, p. 58-69.

8. Nusselt W. Die Oberflächenkondensation des Wasserdampfes. Zeitschrift VDI. 1916. №60. p. 541-546, 568-575. 9. Rifert V., Sereda V. Condensation inside smooth horizontal tubes: Part 1. Survey of the methods of heatexchange prediction. Thermal Science, 2015, Vol. 19, No. 5, p. 1769-1789.

10. Риферт В. Г., Барабаш П. А., Горин В. В., Середа В. В. Теплообмен при конденсации внутри горизонта- 
льных гладких труб. Совершенствование метода расчета теплообмена. Холодильна техніка та технологія. 2015. № 6 (51). C. 26-34.

11. Sing A., Ohadi M., Dessiatoun S. Empirical modeling of stratified-wavy flow condensation heat transfer in smooth horizontal tubes. ASHRAE Transactions, 1996, Vol. 102, No. 2, p. 596-603.

12. Macdonald M., Garimella S. Hydrocarbon condensation in horizontal smooth tubes: Part II - Heat transfer coefficient and pressure drop modeling. International Journal of Heat and Mass Transfer, 2016, Vol. 93, p. 1248-1261.

13. Chen S., Wang Y., Yuan D. Circumferential distribution of local heat transfer coefficient during steam stratified flow condensation in vacuum horizontal tube. International Journal of Heat and Mass Transfer, 2017, Vol. 114, p. 816825.

14. Консетов В. В. К вопросу о теплоотдаче при конденсации пара внутри горизонтальных труб // Известия
Вузов. Энергетика. - Вып. 12. - М., 1961.

15. Консетов В. В. Исследование теплоотдачи при конденсации чистого насыщенного пара внутри труб: автореф. канд. дис. - Л.: ВВМОЛУ, 1962. - 17 с.

16. Cavallini A., Censi G., Del Col D., Doretti L., Longo G., Rossetto L. Experimental investigation on condensation heat transfer and pressure drop of new refrigerants (R134a，R125，R32，R410A， R236ea) in a horizontal smooth tube. International Journal of Refrigeration, 2001, Vol. 24, No. 1, p. 73-87.

17. Yu J., Koyama S., Haraguchi H., Momoki S., Ishibashi A. Boiling and condensation of alternative refrigerants in a horizontal smooth tube. Reports of Institute of Advanced Material Study, Kyushu University, 1996, Vol. 9, No. 2, p. 137-154.

Отримана в редакції 04.01.2019, прийнята до друку 05.02.2019

\title{
Method for heat transfer prediction under stratified flow conditions in condensing inside horizontal pipes
}

\author{
V. V. Gorin', V. V. Sereda ${ }^{2}$, P. O. Barabash ${ }^{3}$ \\ ${ }^{1}$ Odessa State Academy of Technical Regulation and Quality, Odessa \\ ${ }^{2}$ National University of Water Management and Nature Resources Use, Rivne \\ ${ }^{3}$ National Technical University of Ukraine “Igor Sikorsky Kyiv Polytechnic Institute”, Kyiv
}

\begin{abstract}
In modern condensers of air conditioning systems, heat pumps, evaporators of seawater desalination systems and heaters of power plants, the process of vapour condensation is carried out mainly inside the horizontal tubes and channels. Heat transfer processes occurring in condensers have a significant effect on the overall energy efficiency of the mentioned systems. In this paper, the experimental investigations of heat transfer during condensation of freons $R 22, R 406 a$ and $R 407 \mathrm{c}$ in the plain smooth tube with $d=17 \mathrm{~mm}$ were carried out with the following parameters: saturation temperature - $35 \div 40{ }^{\circ} \mathrm{C}$, mass speed $-10 \div 100 \mathrm{~kg} /\left(\mathrm{m}^{2} \mathrm{~s}\right)$, massive steam content $-0.8 \div 0.1$, specific heat flux - $5 \div 50$

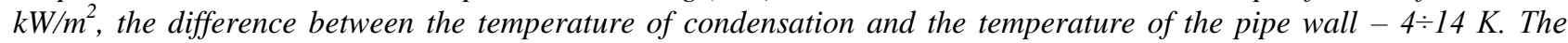
unique measurements of heat fluxes and heat transfer coefficients local by circumference were carried out with the thick wall method during different condensation modes. It can be inferred that at the top part of the tube, with the increase of the heat flux, the thickness of the condensate film increases, which leads to the decrease in heat transfer. At the bottom of the tube, the increase in the heat flux enhances heat transfer, that is characteristic of the turbulent liquid flow in the tube. The obtained results allowed improving a heat transfer method for steam condensation, which takes into account the influence of condensate flow in the lower part of the tube on the heat transfer. This method generalizes with sufficient accuracy (error $\pm 30 \%$ ) the experimental data on condensation of freons $R 22, R 134 a, R 123, R 125, R 32, R 410 a$ under the stratified flow conditions. Using this method for designing heat exchangers, which utilize such types of fluids, will increase the efficiency of energy systems.
\end{abstract}

Keywords: Condensation; Heat transfer coefficient; Plain tube; Stratified flow.

\section{References}

1. Gorin V. V., Sereda V. V. (2018) Hydrodynamics and heat transferin vapour condensing inside horizontal tubesat stratified phase flow. Review. Refrigeration engineering and technology, 54(4), 17-26. Doi: https://doi.org/10.15673/ret.v54i4.1121

2. Sereda V. V., Gorin V. V. (2018) Gidrodinamika i teploobmin pid chas kondensatsii pari robochih rechovin $\mathrm{u}$ seredini gorizontalnih trub u razi stratifikovanogo rezhimu techii faz. Rozrahunok teploviddachi. Integrovani tehnologii ta energozberezhennia, 4, 48-56. (in Ukrainian) 3. Thome J., El Hajal J., Cavallini A. (2003) Condensation in horizontal tubes. Part 2: New heat transfer model based on flow regimes. International Journal of Heat and Mass Transfer, Vol. 46, No. 18, 3365-3387. Doi: https://doi.org/10.1016/s0017-9310(03)00140-6

4. Cavallini A., Del Col D., Doretti L., Matkovic M., Rossetto L., Zilio C., Censi G. (2006) Condensation in horizontal smooth tubes: a new heat transfer model for heat exchanger design. Heat transfer engineering, Vol. 27, No. 8, 31-38. https://doi.org/10.1080/01457630600793970

5. Shah M. An improved and extended general correlation for heat transfer during condensation in plain tubes. ASHRAE Transactions, 2009, No. 15, 889-913.

6. Rifert V., Sereda V., Gorin V., Barabash P., Solomaha A. (2018) Substantiation and the range of application of a new method for heat transfer prediction in condensing 
inside plain tubes. Energetika, Vol. 64, No. 3, 146-154. https://doi.org/10.6001/energetika.v64i3.3807

7. Rifert V., Sereda V., Gorin V., Barabash P., Solomaha A. (2018) Restoration of correctness and improvement of a model for film condensation inside tubes. Bulgarian Chemical Communications, Vol. 50, No. K, p. 58-69.

8. Nusselt W. (1916). Die Oberflächenkondensation des Wasserdampfes. Zeitschrift VDI. No.60, 541-546, 568575.

9. Rifert V., Sereda V. (2015) Condensation inside smooth horizontal tubes: Part 1. Survey of the methods of heatexchange prediction. Thermal Science, Vol. 19, No. 5 , 1769-1789. Doi: https://doi.org/10.2298/tsci140522036r

10. Rifert V. G., Barabash P. A., Gorin V. V., Sereda V. V. (2015) Condensation heat transfer inside a horizontal smooth tubes. Improvement of heat transfer calculating method. Refrigeration engineering and technology, 51(6), 26-34. https://doi.org/10.15673/0453-8307.6/2015.39294

11. Sing A., Ohadi M., Dessiatoun S. (1996) Empirical modeling of stratified-wavy flow condensation heat transfer in smooth horizontal tubes. ASHRAE Transactions, Vol. 102, No. 2, p. 596-603.

12. Macdonald M., Garimella S. (2016) Hydrocarbon condensation in horizontal smooth tubes: Part II Heat transfer coefficient and pressure drop modeling. International Journal of Heat and Mass Transfer, Vol. 93, p. 1248-1261. https://doi.org/10.1016/j.ijheatmasstransfer.2015.09.019
13. Chen S., Wang Y., Yuan D. (2017) Circumferential distribution of local heat transfer coefficient during steam stratified flow condensation in vacuum horizontal tube. Int. Journal of Heat and Mass Transfer, 114, 816-825. https://doi.org/10.1016/j.ijheatmasstransfer.2017.06.042

14. Koncetov V. V. (1961) K voprosu o teplootdache pri kondensatsii para vnutri gorizontalnykh trub. Izvestiia vuzov. Energetika, 12

15. Koncetov V. V. (1962) Issledovanie teplootdachi pri kondensatsii chistogo nasyschennogo para trub: autoreferat kand. diss. VVMOLU, $17 \mathrm{p}$.

16. Cavallini A., Censi G., Del Col D., Doretti L., Longo G., Rossetto L. (2001) Experimental investigation on condensation heat transfer and pressure drop of new refrigerants (R134a, R125, R32, R410A, R236ea) in a horizontal smooth tube. International Journal of Refrigeration, Vol. 24, No. 1, 73-87. https://doi.org/10.1016/s01407007(00)00070-0

17. Yu J., Koyama S., Haraguchi H., Momoki S., Ishibashi A. (1996) Boiling and condensation of alternative refrigerants in a horizontal smooth tube. Reports of Institute of Advanced Material Study, Kyushu University, Vol. 9, No. 2, 137-154.

Received 04 January 2019 Approved 05 February 2019 Available in Internet 03 March 2019 